\title{
Labor Productivity And Real Wages In Macedonia: An Overview Before And After The Global Economic Crisis
}

\author{
Predrag Trpeski, PhD \\ Ljupcho Eftimov, PhD \\ Marijana Cvetanoska, MSc \\ Faculty of Economics - Skopje,
}

Ss. Cyril and Methodius University in Skopje, Republic of Macedonia

doi: 10.19044/esj.2016.v12n10p352 URL:http://dx.doi.org/10.19044/esj.2016.v12n10p352

\begin{abstract}
The aim of the paper is to examine the relationship between the labor productivity and real net wages in Macedonia at the level of the whole economy, and in the sectors of industry and agriculture, both, in the period 2006-2015, i.e. shortly before the commencement and after the Great financial and economic crisis. The paper starts from the assumption that greater labor productivity causes changes in real net wages which are in the same direction. Studies that are previously made show that there is an expressed quantitative relationship between the labor productivity and real net wages in Macedonia in the period 1995-2003. But results obtained in this paper show that the Great financial and economic crisis has influence on this relations. Thus, quantitative relationship between labor productivity and real net wages in the analyzed period is very low, and even that their relationships are with the opposite sign. This leads to the conclusion that during and the period after the crisis, changes in labor productivity did not have an impact on the real net wages in Macedonia, or they had a little impact, and in some cases the impact is in the opposite direction. Taking into consideration that in the period during and after crisis are recorded small but permanent increasing of the wages in the country, it is obvious that such increase is not due to changes in labor productivity but more to other factors.
\end{abstract}

Keywords: Productivity, real net wage, agriculture, industry

\section{Introduction}

Although the reasons for differences in the level of economic development among countries are numerous, generally, we can start from the assumption that differences in economic development are due to differences 
in productivity and factors that do not determine it: physical capital, human capital, natural resources and technological knowledge. In the long run, the only way to increase economic growth and raise living standards is through increased productivity. In the long term, the effects of the increased productivity on the growth of living standards are manifested in a rise in real wages. Labor productivity is one of the indicators that show how efficiently labor force is performing. Relationship of labor productivity and wages has always been an essential economic and legal concern.

Economists recognize the importance of the difference in productivity growth rate of $1 \%$ or $2 \%$ very well, while the non economists, even people from the business sphere may seem these rates approximately as same. How important is the rate of productivity growth can be seen from the famous mathematical rule 70. According to this rule, if the number 70 is divided by the productivity growth rate, it will be derived years needed for real output per worker to be doubled. Hence, if the productivity growth rate is $1 \%$, it would take 70 years for real output and, hence, real income per worker to double. If the rate of productivity growth is $2 \%$, then the required period halves at 35 years and with a growth rate of $3 \%$, the period is 23.3 years.

In the Republic of Macedonia in the period 1995-2007, the average growth rate of GDP per worker was 4.76\% (Trpeski \& Tashevska 2009, p. 106). Hence, it can be concluded that it takes 14.7 years (15.1 years or if it goes with the application of rule 72) for real GDP per worker to double.

The main objective of the paper is to examine the relationship between labor productivity and real net wages in the country in the period and after the Great financial and economic crisis of 2007. To learn more about the situation in Macedonia in the period immediately before and after the Great World Economic Crisis, in a separate section of this paper will be discussed relations between the real net wages and labor productivity in Macedonia. Because we were limited in terms of data available for most sectors, the relationship between the real net wages and productivity is examined at the level of the whole economy and the level of industry and agriculture sectors.

The first part of the paper is focused on an observation of the relationship between labor productivity and real wages, while the second part is the literature review. The methodological aspects are analysed in the third part. In the fourth part of the paper the unit root test and regression model are implemented based on the data from the National Bank of the Republic of Macedonia in which the correlation and relationship are explained, and the results of the model are discussed. 


\section{Literature review}

The economic literature has many papers that examined the link between real wages and labor productivity. Of course they all have different approaches and aspects of research. Studies set out from establishing simple models for determining the correlation between wages and labor productivity to develop models for determining their interdependence and conditionality. In the eighties of the last century, there were quite current models that examine the conditionality of labor productivity from wages. Advanced models include models of wages for performance. They point out that greater wages increase worker productivity. (Yelen 1984, p. 200-205, Mankiw \& Romer 1991, p.p. 113-121 and Trpeski, 2006).

Feldstein (2008) answers the question whether wage growth reflects an increase in productivity. He noted that the level of productivity in the United States doubled in the period 1970-2006 in non- agricultural sector. Wages in the same period, annually grew of approximately the same rate. Before him Boswotrh and Perry (1994) examined the link between productivity and real wages in the United States. Sharpe et al. (2008) are proving that the most direct mechanism through which labor productivity affects the standard of living is real wages. Klein (2012) examines the relationship between real wages, labor productivity and employment trends in South Africa.

Other similar studies have been made in some of the transition economies. Thus, Tamasauskiene and Stankaityte (2013), examine the relationship between wages and labor productivity in Lithuania and they conclude that in the period 2005-2010, regional differences in labor productivity are greater than the differences in wages.

Broadberry and Byrhop (2009) analyze real wages and labor productivity in the UK and Germany in the period 1871-1938. They concluded that the average British worker is better than in Germany, but there are significant differences among the major sectors in these countries. At the level of the whole economy, the gap that occurs in the real wage is approximately the same as the gap in labor productivity, but there are significant differences at the level of sectors. Thus, the German industrial worker was less paid than British, but the employees in the agriculture and service sectors in Germany were better paid.

Kajzer et al. (2007) examine the relationship between real wages and productivity in Slovenia and, among other things, they concluded that in the period from the second half of the nineties of the last century until the publication of the paper, the real growth of average gross wage per worker lags behind productivity growth.

Trpeski (2006) examine the relationship between labor productivity and real net wages in Macedonia for the period 1995-2003 and found that at 
the level of the whole economy there is a great direct quantitative relationship with correlation coefficient of $0.97 \%$ between the average net wage and labor productivity, calculated as GDP per worker, while among the analyzed sectors, the highest correlation coefficient between productivity and wages has the transport and communications sector and it is 0.91 .

\section{Methodological approach}

One of the basic issues in the examination of the links between wages and productivity is setting the methodological concept of productivity. Therefore, for the purposes of labor, there will be distinguished several different concepts of productivity, such as: 1. partial vs. total factor productivity; 2. output per worker vs. output per working hour; 3 . the level of productivity vs. productivity growth rates and 4. cyclical behavior of productivity.

Essential for this paper is to make a difference between partial productivity and total factor productivity. Partial productivity refers to the productivity of the individual factors of production, or it is defined as the ratio between output that is obtained by engaging the appropriate factor of production and the amount of involved units of that factor. Best known partial measure of productivity is labor productivity. Total factor productivity known as 'Solow residual' refers to the increase in output that can not be explained by the increase in factors of production, capital and labor, i.e. it is the increase in output as a result of technological progress. Total factor productivity, primarily depends on technological improvements in the production of goods and services as well as improving the skills of workers, but also by other factors - investment in the commercialization of new products, reduction in prices for some important inputs, etc. (Fiti 2009, p. 133-136).

The aim of this paper is analyzing the partial productivity, i.e. which is the labor productivity.

Labor as an input to the production of goods and services can be measured in two ways: as the average annual number of employees or as the total number of working hours per year. The second way of expressing labor as an input in the production process is more suitable for determining the labor productivity. But in the calculation of productivity it should be clearly define how the labor as an input is measured. It is important because growth rates in output per worker and per working hour can be quite different depending on how many overtime hours are there in the economy. Hence, the comparison of labor productivity in international frameworks should be done very carefully and should be always taken with some degree of reserve because there are large differences in the number of hours that an employee realizes annually among the countries in the world. For example, a worker in 
the United States realize annually more hours than workers in any European country. Hence, in the United States measurement of productivity based on output per worker expresses productivity in a better way than measuring productivity through the relevant measure - output per worked hour. For example, in Norway in 2001, GDP per employee amounted $81.5 \%$ of GDP per employee in the US, but $110.6 \%$ of GDP per employee, calculated on the basis of a working hour. The difference is $29.1 \%$. In the Netherlands, differences in productivity calculated by the two measures are great and amounts $28.4 \%$, i.e. $73.4 \%$ of the level of productivity in the United States measured on the basis of output per worker, up to $101.8 \%$ of the productivity in the United States determined by working hours (Sharpe 2002, p. 34-35).

For the purposes of this paper, the output per worker will be taken as an input for calculating the labor productivity and that is for two reasons:

First, it is simple to calculate the productivity for a longer period of time, which is quite important for us because for our research longer series of movement in labor productivity are needed;

Second, the overtime work or overtime working hours in the past period in Macedonia are quite rarely and incompletely registered.

It is also very important to make a difference between the level of productivity and productivity growth rate. In this paper we use both measures for analyzing the labor productivity in Macedonia. The level of productivity shows how much GDP per worker is accomplished in an appropriate year, while the growth rates of productivity show the change in two different periods.

Examining the relationship between labor productivity and wages in Macedonia are based on official data of the State Statistical Office and National Bank of Macedonia. Data on GDP, wages, employment and productivity for the total economy, and for the industry and agriculture sectors are presented in Annex 1, Table 1.

\section{Labor productivity and real wages in Macedonia}

Examination of the relationship between real net wages and labor productivity in Macedonia is made for the total economy, and for the industry and agriculture. Thus, to see the impact of the Global economic crisis on the relationship between productivity and wages, this period is divided into three sub - periods: the first sub-period is 2006(Q1) - 2008(Q4), the second sub-period is 2009(Q1) - 2012(Q4) and the third sub-period is 2013(Q1) - 2015(Q4). For each period separately is set a regression model which is explained in more details in the section that follows. Before the approach to conducting the regression, a Unit Root test for testing the stationary of the series is done. Unit roots are significant in examining the stationary of a time series because a non-stationary regressor invalidates 
many empirical results. The presence of a stochastic trend is determined by testing the presence of unit roots in time series data. In this study, unit root test is tested using Augmented Dickey-Fuller test. The test showed that the series for the total economy, industry and agriculture are non-stationary, and then it is made the first differentiation where series proved stationary after the Augmented Dickey-Fuller test. The regression model is set on the first level of differentiation of the series wages and productivity.

Before we analyze the relationship between the real net wage and the changes in labor productivity, first we made an examination of their interdependence. The aim is to determine whether between variations of the labor productivity and real wages exist quantitative alignment and if there is how strong the relationship is. Based on the calculations for the period from 2006(Q1) - 2015(Q4) the following results for the coefficients of correlation are:

Table 1. Correlation coefficient for the period 2006 - 2015

\begin{tabular}{|c|c|}
\hline Total economy & 0.226660 \\
\hline Industry & 0.463321 \\
\hline Agriculture & -0.021050 \\
\hline
\end{tabular}

Source: Authors own calculations.

Correlation coefficients show that on the level of total economy and the industry there is a positive correlation, which is very weak on the level of total economy and more pronounced for the industry. In agriculture the correlation between labor productivity and salaries is not only very weak, but it is inverse, too.

\section{Labor productivity and real wages on the level of total economy}

To determine the link between the real net wage and labor productivity in Macedonia, i.e. to see if a change in productivity changes the real net wage, we are setting the following linear regression model:

$$
\mathbf{W}=\boldsymbol{\beta}_{\mathbf{0}}+\boldsymbol{\beta}_{1 *} \mathbf{P}+U_{t}
$$

where $\mathrm{W}$ is real wage, $\mathrm{P}$ is labor productivity, and $U_{t}$ is a residual.

Estimated linear regression model for Macedonia at the level of the total economy has the following form: 
Table 2. Simple regression model for total economy in Macedonia

\begin{tabular}{|c|c|c|c|}
\hline Total economy & $\beta_{0}$ & $\beta_{1}$ & $R$-squared \\
\hline 2006(Q1)-2015(Q4) & $235.2356^{*}$ & -0.006763 & 0.014124 \\
& $(77.49774)$ & $(0.009288)$ & \\
\hline 2006(Q1)-2008(Q4) & $319.0236^{*}$ & $0.017535^{* *}$ & 0.380843 \\
& $(76.61361)$ & $(0.007453)$ & \\
\hline 2009(Q1)-2012(Q4) & 232.0559 & $-0.032355^{* * *}$ & 0.196142 \\
& $(153.006)$ & $(0.017506)$ & \\
\hline 2013(Q1)-2015(Q4) & 98.78556 & -0.00291 & 0.002749 \\
& $(91.10758)$ & $(0.01753)$ & \\
\hline
\end{tabular}

Source: Authors own calculations.

Notes: *,**,*** denote significance at $1 \%, 5 \%$ and $10 \%$ respectively. Standard errors are reported in parentheses.

From the table we can see that if labor productivity increases by 1 percentage point, this leads to a decrease in real net wages for insignificant 0.006763 percentage points. This leads to the conclusion that changes in labor productivity have a low impact on changes in the real net wage in Macedonia. Also, the coefficient of determination is very low and shows that $1.41 \%$ of the changes in real wages are explained by the changes in labor productivity. From a statistical point of view, these results do not show a satisfactory level of statistical significance.

On the other hand, the estimated linear model for the period from 2006(Q1) - 2008(Q4) shows that if labor productivity increases by 1 percentage point, this leads to an increase in real net wage only for 0.017535 percentage points. This leads to the conclusion that changes in labor productivity in this period has very low impact on changes in the real net wage in Macedonia.

However, the results for this period have a satisfactory level of statistical significance. Obtained p-value is lower than the significance level of 0.05 and the regression coefficient $\beta 2$ is statistically significant. The coefficient of determination is quite high and shows that, in the 2006(Q1) 2008(Q4), 38.08\% of the changes in real wage are explained by the changes in productivity. $\quad$ For the period 2009(Q1) - 2012(Q4), i.e. during the Global economic crisis, increased labor productivity by 1 percentage point leads to a decrease in real net wages for 0.032355 percentage points. This suggests that changes in labor productivity have very low impact on changes in the real net wage in Macedonia. Obtained p-value is lower than the level of significance of 0.1 and shows that the regression coefficient $\beta 2$ is statistically significant. Also, the coefficient of determination is very low and shows that $19.61 \%$ of the changes in real wage are explained by changes in productivity. From a statistical perspective, the results for the period 2013(Q1) - 2015 (Q4) do not show a satisfactory level of statistical significance. 


\section{Labor productivity and real wages in industry in Macedonia}

Estimated linear model for the period from 2006(Q1) -2015(Q4) as well as for sub-periods in the industry sector has the following form:

Table 4: Simple regression model for the industry in Macedonia

\begin{tabular}{|c|c|c|c|}
\hline Industry & $\beta_{0}$ & $\beta_{1}$ & $R$-squared \\
\hline 2006(Q1)-2015(Q4) & $249.8706^{*}$ & 0.009567 & 0.012194 \\
& $(79.60122)$ & $(0.014156)$ & \\
\hline 2006(Q1)-2008(Q4) & $258.2316^{*}$ & 0.008187 & 0.029732 \\
& $(66.74642)$ & $(0.01559)$ & \\
\hline $2009(\mathrm{Q} 1)-2012(\mathrm{Q} 4)$ & 301.0824 & 0.00365 & 0.000611 \\
& $(189.7052)$ & $(0.039441)$ & \\
\hline 2013(Q1)-2015(Q4) & $177.5338^{* *}$ & 0.013111 & 0.149503 \\
& $(73.41657)$ & $(0.009889)$ & \\
\hline
\end{tabular}

Source: Authors own calculations.

Notes: *,**,*** denote significance at $1 \%, 5 \%$ and $10 \%$ respectively. Standard errors are reported in parentheses.

From the table it can be seen that if labor productivity in the industry sector changes by 1 percentage point in the examined period, this leads to a very low change in real net wage of 0.009567 percentage points. Changes in productivity for the sub-periods 2006(Q1) -2008(Q4), 2009(Q1) -2012(Q4) and 2013(Q1) -2015(Q4) by 1 percentage point will affect the real wages for $0.008187,0.00365$ and 0.013111 percentage points, respectively.

This leads to the conclusion that changes in labor productivity in Macedonia does not affect changes in real net wage in the industry. Also, low coefficients of determination show that changes in wage can not be explained by changes in productivity for the analyzed period and for the subperiods. From a statistical point of view, these results do not show statistical significance.

\section{Labor productivity and real wages in agriculture in Macedonia}

Estimated linear model for the agriculture sector for the period 2006(Q1)-2015(Q4), as well as for sub-periods is presented in the following table:

Table 4: Simple regression model for the industry in Macedonia

\begin{tabular}{|c|c|c|c|}
\hline Agriculture & $\beta_{0}$ & $\beta_{1}$ & $R$-squared \\
\hline 2006(Q1)-2015(Q4) & $158.5487^{* * *}$ & $0.005173^{* * *}$ & 0.095083 \\
& $(78.46223)$ & $(0.002624)$ & \\
\hline 2006(Q1)-2008(Q4) & $202.3388^{* * *}$ & $0.008192^{* *}$ & 0.463205 \\
& $(103.4361)$ & $(0.002939)$ & \\
\hline 2009(Q1)-2012(Q4) & 189.093 & -0.001854 & 0.020441 \\
& $(115.2383)$ & $(0.003429)$ & \\
\hline 2013(Q1)-2015(Q4) & 25.68549 & $0.031591^{*}$ & 0.696152 \\
& $(107.6716)$ & $(0.0066)$ & \\
\hline
\end{tabular}

Source: Authors own calculations.

Notes: *,**,*** denote significance at $1 \%, 5 \%$ and $10 \%$ respectively. Standard errors are reported in parentheses. 
The table shows that if the labor productivity in agricultural increase by 1 percentage point for the entire period, it will lead to an increase in real net wage for insignificant 0.005173 percentage points. This leads to the conclusion that in the agricultural sector, in the same period, changes in labor productivity have very low impact on the real net wage and results show a statistical significance of $0.1 \%$.

In the period before the crisis, 2006(Q1) - 2008(Q4) change in labor productivity by 1 percentage point would lead to increase in real net wage by low 0.008192 percentage points. Changes in labor productivity in this period have very low impact on the changes in real net wage in Macedonia. However, $46.31 \%$ of the changes in real wage can be explained by changes in productivity and the results show statistical significance.

On the other hand, the model applied for the period of the crisis shows that changes in real wage do not depend on changes in labor productivity in agriculture and changes in real wages can not be explained by changes in labor productivity. Increased labor productivity by 1 percentage point lead to a reduction in real net wage for low 0.001854 percentage points.

In the last analyzed period 2013(Q1) - 2015(Q4) changes in productivity by 1 percentage point causes a change, i.e. an increase in real wages in agriculture for 0.031591 percentage points. In the period after the crisis $69.62 \%$ of changes in real wages can be explained by changes in productivity. The results show a satisfactory level at statistical significance of 0.01 , which means that in the post-crisis period labor productivity has an impact on real wages in agriculture.

\section{Conclusion}

Existing studies which are made in the middle of the first decade of this century show that labor productivity expressed as GDP per employee, grew at an average rate of $6.8 \%$. However, this high growth rate of GDP per employee is not only due to the increase in real GDP in that period which has seen an average annual rate of $3.1 \%$, but to the reduction of employment. In fact, employment in the period from 1995 to 2003 was declining at an average annual rate of $-3.53 \%$. Studies for this period show that on the level of total economy there is a high direct quantitative relationship between average net wages and productivity, i.e. on the level of total economy the correlation coefficient is 0.97 .

But these relations between labor productivity and real wages are changing for the period after 2008. Changes in real net wages in the period after 2007 are accompanied by changes in productivity but in the opposite direction (Annex 2, Figure 1). In the period when the effects of the crisis were emerged until its completion in 2012 the real wages in Macedonia have 
increased by $5.45 \%$ and labor productivity has showed negative growth rate of $1.63 \%$. In recent years real wages in Macedonia are increasing more than productivity. In the period after the crisis, from 2013 to 2015, average growth rate of labor productivity on the level of total economy is $1.99 \%$, while wages have increased by $2.04 \%$.

If we analyze separately, the agriculture sector for the period of the crisis shows negative rate of productivity growth of $11 \%$, while real wages are growing at an average rate of 5.63\%. After the crisis, the changes in labor productivity are aligned with changes in real wages where the rates of annual growth are $1.99 \%$ and $1.29 \%$, respectively. In the industry, labor productivity growth rate in the post-crisis period is greater than the real wages growth rate.

In fact, when an economy is coming out of recession productivity tends to rise more rapidly because labor gets used more effectively. The result is that real wage does not rise as rapidly as productivity. When an economy slows, productivity declines or grows more slowly. The results in this paper for the relation between productivity and wages in Macedonia are a source of substantial controversy. The measurement of productivity is complex and the methodologies chosen to construct productivity estimates can greatly influence the estimations.

Therefore, in Macedonia there is no strong relationship between labor productivity and real wages in the post crisis period. The Great financial and economic crisis has influence on these relations. The relationship between wages and labor productivity is important since the standard of living and distribution of incomes between labor and capital depend upon it. Wages are under the influence of many other factors, depend on the level of socioeconomic development, the standard of living there, qualifications, competences of employees, etc. In the case of Macedonia, while analyzing the relationship between wages and labor productivity economic sectors (specificity, characteristics of a business, qualifications of employees, etc.) must be analyzed.

\section{References:}

Bosworth, B. and Perry, G., (1994), "Productivity and Real Wages: Is There a Puzzle?”, Brookings Papers on Economic Activity, Brookings institution.

Broadberry, S. and Burhop, C. (2009), "Real Wages and Labour Productivity in Britain and Germany, 1871-1938: A Unified Approach to the International Comparison of Living Standards”, Preprints of the Max Planck Institute for Research on Collective Goods, Max Plank Institute, Bonn.

Feldstein, M., (2008), “Did Wages Reflect Growth in Productivity?”, American Economic Association, Annual meeting on January 5. 
Fiti, T., (2009), Phenomenology of economic crisis, Faculty of EconomicsSkopje.

Kajzer, A., Jurancic, S., Kovacic, S., Kraigher, T. and Sustepsic, J. (2007), "Wages, productivity and competitiveness", Economic Issues 2007, Institute of Macroeconomic Analysis and Development, Slovenia. (pp. 43-72)

Klein, N. (2012), "Real Wage, Labor, Productivity and Employment Trends in South Africa: A Closer Look”, IMF Working Paper 12/92.

Mankiw, G. and Romer, D. (1991b), New Keynesian EconomicsCoordinating Failures and Real Rigidities, Vol. 2, Cambridge, MIT Press.

National Bank of the Republic of Macedonia, Quarterly Bulletin 4/2015

Sharpe, A. (2002), "Productivity concepts, Trends and Prospects: An Overview", The Review of Economic Performance and Social Progress, Centre for the Study of Living Standards, Ontario, Canada.

Sharpe, A., Arsenault, J.F. and Harrison, P. (2008), The relations between Labour Productivity and Real Wage Growth in Canada and OECD Countries, Centre for the Study of Living Standards, Ottawa, Ontario.

Tamasauskiene, Z. and Stankaityte, A. (2013), "Evaluation of the relationship between Wages and Labour Productivity in Lithuania: Territorial and Sectoral Approaches”, Socialiniai tzrimai/Social Research Nr. 1(30), Siauliai University, Faculty of social science, Lithuania.

Trpeski, P., and Tashevska, B., (2009), "Labor Productivity and Wages in the Republic of Macedonia”, RTE Revista Tinerilor Economisti (The Young Economists Journal), Vol. VII, No. 13, Romania.

Yelen, J. (1984), "Efficiency-Wage Models of Unemployment”, American Economic Review, May, Vol. 74. 
Annex 1

Table 1.Labor productivity and real wages in Macedonia (in denars)

\begin{tabular}{|c|c|c|c|c|c|c|c|c|c|c|c|c|}
\hline & \multirow[b]{2}{*}{ GDP* } & \multicolumn{3}{|c|}{ Total economy } & \multicolumn{4}{|c|}{ Agriculture } & \multicolumn{4}{|l|}{ Industry } \\
\hline & & Employees & Productivity & Real wages & GDP* & Employees & Productivity & Real wages & GDP* & Employees & Productivity & Real wages \\
\hline 2006:Q1 & $76,991.00$ & $559,702.00$ & $137,557.13$ & $13,206.67$ & $4,614.00$ & $103,319.00$ & $44,657.81$ & $9,878.67$ & $7,150.00$ & $190,355.00$ & $37,561.40$ & $14,078.87$ \\
\hline 2006:Q2 & $79,988.00$ & $566,293.00$ & $141,248.43$ & $13,427.67$ & $6,548.00$ & $128,519.00$ & $50,949.67$ & $10,115.33$ & $8,789.00$ & $189,630.00$ & $46,348.15$ & $14,230.67$ \\
\hline 2006:Q4 & $86,289.00$ & $578,810.00$ & $149,080.01$ & $13,853.67$ & $11,425.00$ & $101,948.00$ & $112,066.94$ & $10,512.00$ & $8,697.00$ & $176,592.00$ & $49,249.12$ & $14,691.73$ \\
\hline 2007:Q1 & $77,365.00$ & $579,301.00$ & $133,548.88$ & $13,962.33$ & $5,279.00$ & $95,384.00$ & $55,344.71$ & $9,787.33$ & $7,318.00$ & $186,975.00$ & $39,138.92$ & $14,628.47$ \\
\hline 2007:Q2 & $83,626.00$ & $589,254.00$ & $141,918.43$ & $14,287.00$ & $6,860.00$ & $112,982.00$ & $60,717.64$ & $10,444.67$ & $7,408.00$ & $184,622.00$ & $40,125.23$ & $14,774.80$ \\
\hline 2007:Q3 & $89,439.00$ & $598,327.00$ & $149,481.81$ & $14,604.33$ & $7,123.00$ & $117,531.00$ & $60,605.29$ & $10,850.67$ & $7,351.00$ & $181,993.00$ & $40,391.66$ & $14,961.60$ \\
\hline 2007:Q4 & $94,855.00$ & $594,054.00$ & $159,674.04$ & $15,490.33$ & $11,295.00$ & $104,975.00$ & $107,597.05$ & $11,061.33$ & $7,244.00$ & $186,122.00$ & $38,920.71$ & $15,533.73$ \\
\hline 2008:Q1 & $83,620.00$ & $600,593.00$ & $139,229.06$ & $15,430.33$ & $6,073.00$ & $121,238.00$ & $50,091.56$ & $10,822.00$ & $6,622.00$ & $178,848.00$ & $37,025.85$ & $15,581.93$ \\
\hline 2008:Q2 & $91,196.00$ & $607,125.00$ & $150,209.59$ & $15,697.33$ & $8,656.00$ & $129,711.00$ & $66,732.97$ & $11,361.33$ & $7,363.00$ & $186,184.00$ & $39,546.90$ & $15,906.47$ \\
\hline 2008:Q3 & $92,996.00$ & $619,802.00$ & $150,041.46$ & $16,170.67$ & $9,772.00$ & $119,149.00$ & $82,014.96$ & $11,861.00$ & $7,478.00$ & $198,499.00$ & $37,672.73$ & $16,278.00$ \\
\hline 2008:Q4 & $96,367.00$ & $608,541.00$ & $158,357.45$ & $17,080.67$ & $12,927.00$ & $108,896.00$ & $118,709.59$ & $12,711.00$ & $7,268.00$ & $198,590.00$ & $36,598.02$ & $16,911.53$ \\
\hline 2009:Q1 & $86,104.00$ & $618,189.00$ & $139,284.26$ & $19,653.33$ & $6,499.00$ & $120,186.00$ & $54,074.52$ & $14,156.00$ & $6,611.00$ & $181,567.00$ & $36,410.80$ & $19,857.87$ \\
\hline 2009:Q2 & $89,708.00$ & $636,156.00$ & $141,015.73$ & $20,116.33$ & $8,549.00$ & $122,958.00$ & $69,527.81$ & $13,977.33$ & $7,286.00$ & $188,433.00$ & $38,666.26$ & $20,388.80$ \\
\hline 2009:Q3 & $89,512.00$ & $642,541.00$ & $139,309.40$ & $19,891.33$ & $10,145.00$ & $119,474.00$ & $84,913.87$ & $14,536.67$ & $7,761.00$ & $189,239.00$ & $41,011.63$ & $20,541.13$ \\
\hline 2010:Q1 & $90,878.00$ & $615,962.00$ & $147,538.32$ & $20,302.67$ & $5,335.00$ & $109,821.00$ & $48,579.05$ & $14,261.33$ & $6,212.00$ & $182,562.00$ & $34,026.80$ & $20,864.33$ \\
\hline 2010:Q2 & $91,270.00$ & $627,129.00$ & $145,536.25$ & $20,557.00$ & $7,338.00$ & $121,442.00$ & $60,423.91$ & $14,325.00$ & $7,304.00$ & $183,307.00$ & $39,845.72$ & $20,997.33$ \\
\hline 2010:Q3 & $97,119.00$ & $648,773.00$ & $149,696.43$ & $20,464.67$ & $10,278.00$ & $128,825.00$ & $79,782.65$ & $14,282.33$ & $8,213.00$ & $186,077.00$ & $44,137.64$ & $21,109.93$ \\
\hline 2010:Q4 & $95,794.00$ & $659,557.00$ & $145,239.91$ & $20,890.33$ & $10,313.00$ & $126,995.00$ & $81,207.92$ & $14,266.33$ & $8,129.00$ & $189,024.00$ & $43,005.12$ & $21,449.20$ \\
\hline 2011:Q1 & $91,638.00$ & $649,575.00$ & $141,073.78$ & $20,682.33$ & $5,776.00$ & $118,837.00$ & $48,604.39$ & $14,093.00$ & $7,783.00$ & $192,349.00$ & $40,462.91$ & $21,318.60$ \\
\hline 2011:Q2 & $96,665.00$ & $642,809.00$ & $150,379.04$ & $20,864.00$ & $7,311.00$ & $122,698.00$ & $59,585.32$ & $14,870.67$ & $8,745.00$ & $194,047.00$ & $45,066.40$ & $21,596.53$ \\
\hline 2011:Q3 & $96,417.00$ & $648,617.00$ & $148,650.13$ & $20,794.67$ & $10,060.00$ & $123,973.00$ & $81,146.70$ & $14,937.00$ & $8,249.00$ & $197,175.00$ & $41,835.93$ & $21,635.60$ \\
\hline 2011:Q4 & $99,117.00$ & $639,340.00$ & $155,030.19$ & $21,050.45$ & $10,727.00$ & $118,065.00$ & $90,856.73$ & $15,239.61$ & $8,703.00$ & $190,645.00$ & $45,650.29$ & $21,627.02$ \\
\hline 2012:Q1 & $90,713.27$ & $643,668.00$ & $140,931.78$ & $20,896.02$ & $4,826.91$ & $109,222.00$ & $44,193.61$ & $15,107.90$ & $7,067.82$ & $190,928.00$ & $37,018.27$ & $21,468.56$ \\
\hline 2012:Q2 & $97,104.95$ & $648,200.00$ & $149,807.08$ & $20,753.81$ & $6,624.83$ & $119,440.00$ & $55,465.73$ & $15,699.79$ & $8,443.52$ & $194,222.00$ & $43,473.55$ & $21,628.05$ \\
\hline 2012:Q3 & $96,710.24$ & $652,498.00$ & $148,215.38$ & $20,841.78$ & $8,978.15$ & $109,173.00$ & $82,237.79$ & $15,894.00$ & $8,267.72$ & $197,276.00$ & $41,909.42$ & $21,810.57$ \\
\hline 2012:Q4 & $97,558.22$ & $657,849.00$ & $148,298.81$ & $21,119.01$ & $8,009.38$ & $112,504.00$ & $71,191.97$ & $15,824.57$ & $9,309.03$ & $194,784.00$ & $47,791.56$ & $21,769.70$ \\
\hline 2013:Q1 & $93,617.06$ & $668,957.00$ & $139,944.81$ & $21,129.77$ & $5,559.23$ & $130,118.00$ & $42,724.55$ & $15,387.11$ & $7,407.35$ & $196,939.00$ & $37,612.42$ & $21,924.33$ \\
\hline
\end{tabular}




\begin{tabular}{|c|c|c|c|c|c|c|c|c|c|c|c|c|}
\hline 2013:Q2 & $99,843.89$ & $678,467.00$ & $147,161.01$ & $21,126.03$ & $7,056.55$ & $121,487.00$ & $58,084.79$ & $15,392.69$ & $8,901.96$ & $209,606.00$ & $42,469.97$ & $22,324.05$ \\
\hline 2013:Q3 & $101,439.59$ & $682,448.00$ & $148,640.77$ & $21,060.19$ & $9,093.94$ & $127,747.00$ & $71,187.15$ & $15,981.35$ & $9,947.49$ & $209,246.00$ & $47,539.67$ & $22,489.27$ \\
\hline 2013:Q4 & $98,361.56$ & $685,479.00$ & $143,493.17$ & $21,266.74$ & $9,167.95$ & $129,391.00$ & $70,854.63$ & $15,801.78$ & $10,019.02$ & $209,247.00$ & $47,881.33$ & $22,402.47$ \\
\hline 2014:Q1 & $97,271.69$ & $686,277.00$ & $141,738.24$ & $21,091.74$ & $5,988.39$ & $131,005.00$ & $45,711.15$ & $15,235.33$ & $10,722.35$ & $205,075.00$ & $52,285.04$ & $22,692.55$ \\
\hline 2014:Q3 & $105,751.97$ & $690,965.00$ & $153,049.67$ & $21,281.64$ & $9,127.99$ & $124,157.00$ & $73,519.73$ & $16,451.79$ & $13,251.88$ & $212,037.00$ & $62,497.98$ & $23,124.10$ \\
\hline 2014:Q4 & $102,870.44$ & $696,046.00$ & $147,792.59$ & $21,903.96$ & $8,991.90$ & $127,249.00$ & $70,663.78$ & $16,091.96$ & $11,486.25$ & $216,075.00$ & $53,158.60$ & $23,448.16$ \\
\hline 2015:Q1 & $100,641.71$ & $697,248.00$ & $144,341.34$ & $21,444.79$ & $5,778.02$ & $127,185.00$ & $45,430.08$ & $14,877.17$ & $9,716.81$ & $215,815.00$ & $45,023.79$ & $23,058.65$ \\
\hline 2015:Q2 & $104,599.20$ & $699,578.00$ & $149,517.57$ & $21,947.21$ & $7,370.68$ & $128,800.00$ & $57,225.78$ & $15,813.02$ & $10,686.64$ & $214,204.00$ & $49,890.03$ & $23,563.76$ \\
\hline 2015:Q3 & $109,466.52$ & $711,380.00$ & $153,879.11$ & $21,922.36$ & $8,708.68$ & $125,064.00$ & $69,633.82$ & $16,360.65$ & $13,455.34$ & $215,544.00$ & $62,425.04$ & $23,744.76$ \\
\hline 2015:Q4 & $106,848.60$ & $715,758.00$ & $149,280.35$ & $22,301.58$ & $9,100.01$ & $123,456.00$ & $73,710.52$ & $16,212.36$ & $11,623.35$ & $215,711.00$ & $53,883.92$ & $23,979.98$ \\
\hline
\end{tabular}

*GDP is expressed in million

Source: National Bank of the Republic of Macedonia: Quarterly Bulletin 4/2015 


\section{Annex 2.}

Figure 1. Changes in labor productivity and real net wages in Macedonia in the period 20062015

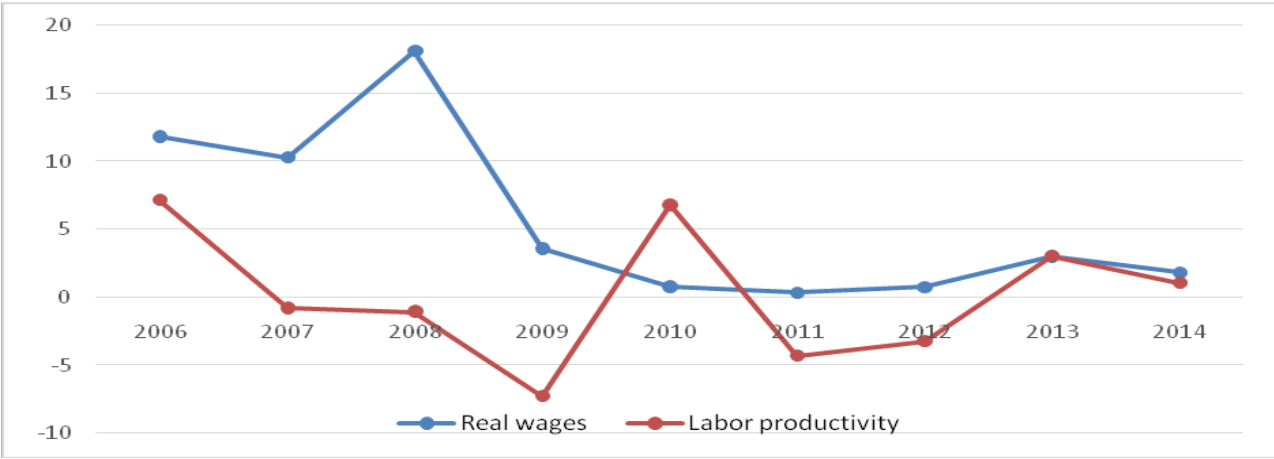

Source: Authors own calculations based on National Bank of the Republic of Macedonia: Quarterly Bulletin 4/2015

Figure 2. Changes in labor productivity and real net wages in Macedonia in the period 20062015 in industry

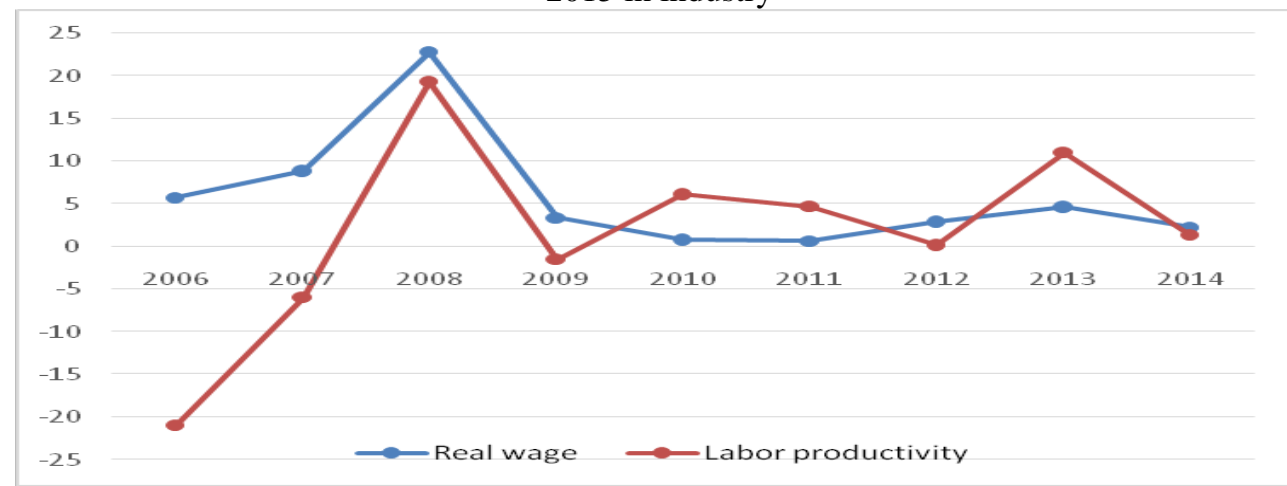

Source: Authors own calculations based on National Bank of the Republic of Macedonia: Quarterly Bulletin 4/2015

Figure 3. Changes in labor productivity and real net wages in Macedonia in the period 20062015 in agriculture

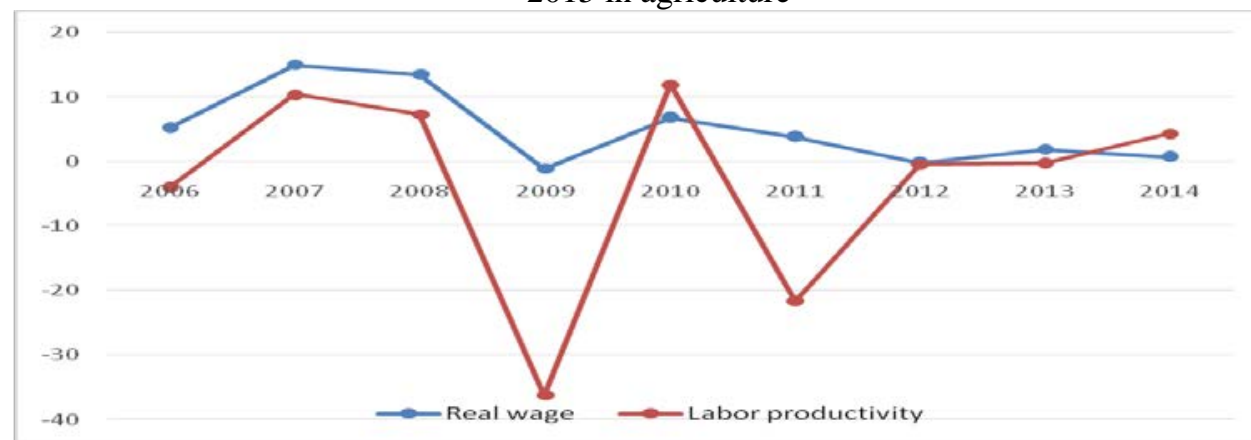

Source: Authors own calculations based on National Bank of the Republic of Macedonia: Quarterly Bulletin 4/2015 